\title{
UNIVERSITYOF
}

FORWARD

THINKING

WESTMINSTER用

WestminsterResearch

http://www.westminster.ac.uk/westminsterresearch

\section{Who Fights Whom? Understanding the Complex Dynamics of Bacteria-Phage Interaction using Anderson Phage Typing System Mohammed, $\mathbf{M}$.}

A copy of the final version of an article published in $\mathrm{J}$ Infect Dis Ther 6(3): 367. doi:10.4172/2332-0877.1000368. It is available from the publisher at:

https://doi.org/10.4172/2332-0877.1000367

(C) 2018 Mohammed M. This is an open-access article distributed under the terms of the Creative Commons Attribution License, which permits unrestricted use, distribution, and reproduction in any medium, provided the original author and source are credited.

The WestminsterResearch online digital archive at the University of Westminster aims to make the research output of the University available to a wider audience. Copyright and Moral Rights remain with the authors and/or copyright owners.

Whilst further distribution of specific materials from within this archive is forbidden, you may freely distribute the URL of WestminsterResearch: ((http://westminsterresearch.wmin.ac.uk/)).

In case of abuse or copyright appearing without permission e-mail repository@westminster.ac.uk 


\section{Who Fights Whom? - Understanding the Complex Dynamics of Bacteria- Phage Interaction Using Anderson Phage Typing System}

\section{Manal Mohammed}

Department of Biomedical Sciences, Faculty of Science and Technology, University of Westminster, UK

*Corresponding author: Dr. Manal Mohammed, Department of Biomedical Sciences, Faculty of Science and Technology, University of Westminster, UK, Tel: +44 (0)35067207; E-mail: m.mohammed@westminster.ac.uk

Received date: May 28, 2018; Accepted date: June 06, 2018; Published date: June 15, 2018

Copyright: $@ 2018$ Mohammed M. This is an open-access article distributed under the terms of the Creative Commons Attribution License, which permits unrestricted use, distribution, and reproduction in any medium, provided the original author and source are credited.

\begin{abstract}
Abbreviations: Abi: Abortive-infection; BREX: Bacteriophage exclusion; CRISPRs: Clustered regularly interspaced short palindromic repeats; DT: Definitive phage types; ICE: Integrative and conjugative element; LPS: Lipopolysaccharide; MDR: Multidrug-resistant; MTases: Methyltransferases; REases: Restriction endonucleases; R-M: Restriction-modification; RNAi: RNA interference; Sie: Superinfection exclusion
\end{abstract}

\section{Commentary}

The global dissemination of multidrug-resistant (MDR) bacteria represents a major threat to public health. Resistance has now been found to drugs that represent the last line of antibiotic defence against some serious infections indicating that the world is on the cusp of 'post-antibiotic era' since there are few clinically validated options for treatment of some such resistant strains and little is in the development pipeline. Bacteriophages or phages for short are viruses that are widely distributed in the environment. They have the ability to attack and destroy bacteria. Phages therefore might offer an alternative to antibiotics for treating resistant bacterial infections [1] however, one of the key limitations to therapeutic use of phages, in particular for empiric therapy of infections, is the limited host range of many phages and the ease of development of bacterial resistance to phages. A solution may be to develop one or a cocktail of engineered phage that can overcome these limitations however an essential step towards this goal is greater understanding of the basis of bacteria-phage interaction.

Although Anderson phage typing system of Salmonella typhimurium is almost obsolete for typing Salmonella [2,3] it provides a valuable model system for study of phage-host interaction. The system distinguishes more than 300 definitive phage types (DT) of Salmonella typhimurium based on their patterns of lysis to a unique collection of Salmonella phages. A recently discovered novel genomic element in Salmonella typhimurium DT30 might contribute to bacterial resistance to phages [4]. Although DT8 and DT30 are similar at the whole genome level they differ in their susceptibility to 10 of the 30 Salmonella typing phages of the Anderson scheme. Preliminary data from a comparative genomic study of DT8 and DT30 revealed that differences in phage susceptibility might be related to acquisition of a novel integrative and conjugative element (ICE) in DT30 and/or loss of a plasmid coding a unique methyltransferase (M.EcoGIX related MTase) present in DT8. By contrast with this instance of striking difference in phage susceptibility between two gnomically closely related taxa; DT8 and DT30, is the genomic diversity that exists with the single phage type; DT193 [5]. This combination of divergent phage susceptibility in closely related strains and indistinguishable phage susceptibility in gnomically diverse isolates presents an ideal model for studying the complex-dynamics of phage-host interaction.
The basis of bacteria-phage interaction is not fully characterised. It has been reported that bacteria have developed different resistance mechanisms against phages [6] however phages can evade these mechanisms $[7,8]$. In general, phages are host specific and that specificity is based primarily on their ability to adsorb to specific cell receptors of the host cells such as a surface protein or lipopolysaccharide (LPS). Bacteria have developed a variety of antiphage barriers that inhibit phage adsorption and attachment to cell surface receptors through blocking of phage receptors and production of extracellular matrix or competitive inhibitors. If phage by-passes the initial antiviral barriers and succeeds in binding to the bacterial cell surface through adapting to new surface receptors or digging for masked receptors by hydrolysing receptors barriers phage can now inject its genome into the bacterial cell and may go through lytic cycle where the host cell is converted to a phage factory producing many phage progenies. The bacterial cell is often destroyed by lysis. Alternatively, the host cell may undergo the lysogenic cycle instead where the infecting-phage genome gets integrated within host chromosome at a unique attachment site (becoming a prophage), remaining in a near-dormant state while phage genes replicate as part of the bacterial chromosome for many cycles of cell division. Interestingly, a lysogen is immune to superinfection by the phage that is the same as or closely related to the integrated phage through the superinfection exclusion (Sie) phenomenon. Sie systems include proteins coded by genes harboured by prophages that can block the entry of phage genome and prevent its injection to the host cell. More recently, it has been reported that the $g t r \mathrm{C}$ gene of the prophage BTP1 of an invasive strain of Salmonella typhimurium can mediate modification of $\mathrm{O}$-antigen receptor thus preventing superinfection by other phages using the same O-antigen co-receptor [9]. Most Salmonella typhimurium strains are lysogenic for one or more prophages. Some of these prorophages belong to phage P22 family. Phage P22 contains SieA and SieB systems that are found in the inner membrane of lysogenic strains preventing infection by other related phages. The molecular mechanisms of Sie systems are still not fully understood. If a phage manages to overcome the Sie system and inject its genome into host cell infection may still be prevented by bacterial restriction-modification (R-M) systems. R-M systems include restriction endonucleases (REases) that have the ability to cut invading phage genome at specific recognition sites and methyltransferases (MTases) that modify recognition sites in the host genome thus protecting it from REases. In some circumstances however, phage genome may also be methylated by the bacterial MTase and can therefore avoid cleavage leading to the initiation of the lytic phage cycle. Phage genome can also be cleaved by the more recently discovered clustered regularly interspaced short palindromic repeat (CRISPRs) loci and CRISPR-associated (Cas) proteins (CRISPR-Cas) immune systems. CRISPR-Cas system is considered as the adaptive 
Citation: Mohammed M (2018) Who Fights Whom?-Understanding the Complex Dynamics of Bacteria-Phage Interaction Using Anderson Phage Typing System. J Infect Dis Ther 6: 367. doi:10.4172/2332-0877.1000367

Page 2 of 2

bacterial immune system that provides acquired immunity against foreign genetic material (of phages and plasmids) through targeting invading genetic material in a sequence-specific manner. The CRISPRCas immunization process is based on neutralizing foreign genetic material for plasmids or phages through a mechanism similar to RNA interference (RNAi). Interestingly, it has been found that phages have developed several by-pass mechanisms to evade bacterial R-M systems through masking and modification of restriction sites within phage genome. Moreover, phages can resist bacterial CRISPR-Cas system via developing anti-CRISPR proteins and antibacterial CRISPR-Cas systems [10].

Finally, bacteria can still target crucial steps in phage replication cycle through induction of selfless bacterial cell suicide using abortiveinfection (Abi) mechanisms to abort phage infection in the remaining non-infected bacterial population or through the recently discovered bacteriophage exclusion (BREX) defense system that provides innate immunity against bacteriophages [11] however, it appears that bacteriophage can escape both Abi and BREX mechanisms.

In conclusion, bacteria-phage interaction is therefore very complex and a good model is crucial to study the molecular basis of this interaction. Anderson phage typing system provides a valuable model system for study of host-phage interaction. Understanding the basis of bacteria-phage interaction will provide insights into phage biology and the development of synthetic phages that can overcome the limitations of phage therapy.

\section{Acknowledgment}

This work received no specific grant from any funding agency.

\section{Conflict of Interest}

There is no conflict of interest.

\section{References}

1. Nobrega FL, Costa AR, Kluskens LD, Azeredo J (2015) Revisiting phage therapy: new applications for old resources. Trends Microbiol 23: 185-191.

2. Anderson ES, Ward LR, Saxe MJ, de Sa JD (1977) Bacteriophage-typing designations of Salmonella typhimurium. J Hyg 78: 297-300.

3. Mohammed M (2017) Phage typing or CRISPR typing for epidemiological surveillance of Salmonella typhimurium? BMC Res Notes 10: 578.

4. Mohammed M, Cormican M (2015) Whole genome sequencing provides possible explanations for the difference in phage susceptibility among two Salmonella typhimurium phage types (DT8 and DT30) associated with a single foodborne outbreak. BMC Res Notes 8: 728.

5. Hampton MD, Threlfall EJ, Frost JA, Ward LR, Rowe B (1995) Salmonella typhimurium DT 193: differentiation of an epidemic phage type by antibiogram, plasmid profile, plasmid fingerprint and salmonella plasmid virulence (spv) gene probe. J Appl Bacteriol 78: 402-408.

6. Doron S, Melamed S, Ofir G, Leavitt A, Lopatina A, et al. (2018) Systematic discovery of antiphage defense systems in the microbial pangenome. Science 359 .

7. Samson JE, Magadan AH, Sabri M, Moineau S (2013) Revenge of the phages: defeating bacterial defences. Nat Rev Microbiol 11: 675-687.

8. Labrie SJ, Samson JE, Moineau S (2010) Bacteriophage resistance mechanisms. Nat Rev Microbiol 8: 317-327.

9. Kintz E, Davies MR, Hammarlof DL, Canals R, Hinton JC, et al. (2015) A BTP1 prophage gene present in invasive non-typhoidal Salmonella determines composition and length of the O-antigen of the lipopolysaccharide. Mol Microbiol 96: 263-275.

10. He F, Bhoobalan-Chitty Y, Van LB, Kjeldsen AL, Dedola M, et al. (2018) Anti-CRISPR proteins encoded by archaeal lytic viruses inhibit subtype ID immunity. Nat Microbiol 3: 461-469.

11. Goldfarb T, Sberro H, Weinstock E, Cohen O, Doron S, et al. (2015) BREX is a novel phage resistance system widespread in microbial genomes. EMBO J 34: 169-183. 